\title{
Lumen
}

Selected Proceedings from the Canadian Society for Eighteenth-Century Studies

\section{Editing Jane: Austen's Juvenilia in the Classroom}

\section{Tobi Kozakewich, Kirsten Macleod et Juliet Mcmaster}

Volume 19, 2000

Material Productions \& Cultural Construction

Culture matérielle \& Constructions discursives

URI : https://id.erudit.org/iderudit/1012324ar

DOI : https://doi.org/10.7202/1012324ar

Aller au sommaire du numéro

Éditeur(s)

Canadian Society for Eighteenth-Century Studies / Société canadienne d'étude du dix-huitième siècle

ISSN

1209-3696 (imprimé)

1927-8284 (numérique)

Découvrir la revue

Citer cet article

Kozakewich, T., Macleod, K. \& Mcmaster, J. (2000). Editing Jane: Austen's Juvenilia in the Classroom. Lumen, 19, 187-201.

https://doi.org/10.7202/1012324ar

Copyright (C Canadian Society for Eighteenth-Century Studies / Sociéte canadienne d'étude du dix-huitième siècle, 2000
Ce document est protégé par la loi sur le droit d'auteur. L'utilisation des services d'Érudit (y compris la reproduction) est assujettie à sa politique d'utilisation que vous pouvez consulter en ligne.

https://apropos.erudit.org/fr/usagers/politique-dutilisation/ 


\section{Editing Jane: Austen's Juvenilia in the Classroom}

Treasured objects in the Ashmolean Museum in Oxford and the British Library, materials that have been carefully preserved from that century to this, are the manuscripts from the hand of the teenage Jane Austen, written during the 1790s: she called them, in humorous imitation of the three-decker novels she was used to reading, Volume the First, Volume the Second, and Volume the Third. Austen is an author so sought after that even established scholars are not customarily permitted to lay hands on these pages, but must look at them through glass or in microfilm. And yet since no manuscript survives of the novels she published in her lifetime (except for the cancelled chapter of Persuasion), these three volumes of juvenilia, like those of the unfinished fragments The Watsons and Sanditon, are particularly valuable for offering insights into her creative process. Students as well as scholars, I suggest, should have access to what the manuscripts can reveal.

The process of editing from manuscript, or indeed of any editing whatsoever, is usually left in the hands of professional scholars; and students of literature receive their texts ready-made, as from the hand of God. Lists of textual variants which they may find in some editions are cheerfully overlooked, as is the 'Note on the Text' which the editor has painstakingly prepared. And yet these same students are very well trained in critical interpretation, and some can readily cook up plausible arguments on the signification of an upper case here or some possible word-play there, when these may be the choices or errors of a modern editor rather than a product of authorial intention. To restore some balance in this training, so that students of literature become conscious that the text to which they bring their interpretive skills is the product not only of an author but also of a multiplicity of editorial decisions, it has been my project to get students editing a text themselves, from manuscript if possible. And if they cannot lay their hands on Austen's holograph, they can work from reproductions, and pass on their findings, and something of their experience, to other students. 
At the CSECS conference where we first gave a version of this paper, every delegate received a copy of Jane Austen's A Collection of Letters, in a scholarly edition prepared largely by students, and published by the Juvenilia Press (see Figure 1). ${ }^{1}$ This is the first time that this work written at about sixteen - has received separate publication; and our edition comes with its own critical introduction, full annotation, and text edited from the manuscript (or rather, a photocopy thereof, which was the best we could do; and the British Library has proved very accommodating to our enterprise).

The Introduction by Heather Harper was an exercise in critical interpretation and contextualising; the annotations were a team effort, in which we divided among us such topics as dress, topography, coaches and travel, literary allusion, and connections with Austen's other works; the illustration - always an enjoyable part of our volumes - was by Laura Nielson; she worked with our designer, Winston Pei (also a student), who brings professional expertise, and who has given our books their distinctive look. Textual editing, which is the focus of this paper, was by Tobi Kozakewich, Kelly Laycock, and Kirsten MacLeod. The whole was a special project in a graduate course on the Romantic novel, in which Austen was one author among several others.

While some of the work on the edition could be done for credit among the assignments for the course, our team-edited volume called for extra research, and a number of meetings and consultations outside of class time; and it was not actually published until well after the course was over. But we had created a book, after all (the secret ambition of many a student of literature). And in the process the students had gathered experience not only in textual editing, annotating, and introducing, but also in such matters as permissions, acknowledgements, quotationchecking, proof-reading, design, and all the other nitty-gritty of scholarly production.

The creative beginnings of a youthful author offer an appropriate training space for the tyro scholar; and the Juvenilia Press, an enterprise in research and pedagogy, is designed to acquaint students with the basics of scholarly editing, as they work alongside more experienced scholars. The mission of the Press is to present scholarly editions of the early writings of major authors, with student involvement in the editing process. Our authors so far include Lady Mary Wortley Montagu, the Brontës, George Eliot, Louisa May Alcott, and even Margaret Atwood, who generously allowed us to publish some early work of hers without royalty. But Jane Austen has been our major standby, and her jubilant juvenilia fortunately have market appeal.

Since its beginnings in the early $1990 \mathrm{~s}^{2}$ the Juvenilia Press has published some twenty-one volumes, and more are in the pipeline. They 




Figure 1 Cover of the Juvenilia Press edition of A Collection of Letters 
have been created by undergraduate as well as graduate students; and they are not necessarily part of a course, but represent different kinds of collaboration between scholars and students. The Press is fortunate that major scholars from widely-spread universities have contributed their expertise and developed their students' skills: Isobel Grundy in Canada, author of the biography of Lady Mary Wortley Montagu that has recently emerged from Oxford University Press, brought us Lady Mary's mini-romance Indamora to Lindamira, written at fourteen in 1704; and since that had not been published before, it provided an impulse for the founding of the Press; Christine Alexander of the University of New South Wales, the major scholar of Charlotte Brontë's juvenilia, has produced a Brontë volume, and plans others; and the American Austen scholars Jan Fergus and Rachel Brownstein have collaborated with their students in editing the young Jane's The History of England, Lesley Castle, and Henry and Eliza. Thus our little Press is making its mark in different countries and on different continents. Moreover, since some of our editions have become texts in other courses, the work of the student editors goes on to enlighten other students.

The editing process is an activity unusual enough in the classroom that some student editors have chosen to write about their experience, in various venues academic, electronic and otherwise. ${ }^{3}$ The present paper is an example.

In her adulatory dedications, which addressed her 'patrons' - usually members of her family - young Jane mimicked the publication conventions of her day. She also jokingly claimed that The History of England and The Beautifull Cassandra had 'attained a place in every library in the Kingdom, and run through threescore Editions': that is, this young author, however playfully, envisaged herself as a professional, participating in the hurly-burly of the publishing world. The Juvenilia Press editions, by presenting these juvenile works as separate volumes rather than in a homogenized collection à la Chapman or Doody and Murray, go some way towards fulfilling that child author's professional ambitions. I hope that the Juvenilia Press does the same for today's student, too.

Our Juvenilia Press editions are the product of team work, and so is this paper. I pass the pen to Kirsten MacLeod, who in turn passes it to Tobi Kozakewich. 
A Collection of Letters, the volume of Austen's juvenilia that we chose to edit, is not, as the title might lead one to believe, composed of real-life letters. Nor is it a series of letters forming a continuous narrative as in the epistolary novels that were so popular in the Eighteenth Century. The letters that make up this manuscript are fictional, with each letter introducing a new narrative situation and a new set of characters, as though young Jane were launching a series of experiments. Perhaps because of its eclectic form, A Collection of Letters has received scant critical attention in comparison with Austen's other juvenile works. ${ }^{4}$ But A Collection of Letters is an important transitional work, containing fine examples of both the parodic burlesque found in earlier juvenilia like Love and Freindship and the more serious concerns of her adult fiction. Thus, on the one hand, Letter the Fifth depicts the ludicrous protestations of a sentimental young suitor who plans to die for love. Reaching the heady heights of sensibility as he imagines that his beloved might actually shed a tear over his corpse, he rapturously declares, 'Ah! ... imagine what my transports will be when I feel the dear precious drops trickle on my face! Who would not die to taste such ecstacy!' (CL 27). ${ }^{5}$ On the other hand, A Collection of Letters contrasts these moments of sheer travesty with a more nuanced approach to characters and themes that contain the seeds of her mature work. Letter the Third, for example, 'from a young Lady in distress'd circumstances,' shows the humiliations suffered by the disadvantaged protagonist from the patronage of the domineering Lady Greville, a woman who sounds and behaves very much like Lady Catherine de Bourgh of Pride and Prejudice: 'Pray Miss Maria,' she asks the 'young Lady' pointedly (and in company too), 'in what way of business was your Grandfather? for Miss Mason \& I cannot agree whether he was a Grocer or a Bookbinder.... I knew he was in some such low way' (CL 12).

The co-existence of Austen's juvenile and adult themes suggested a variety of critical approaches to members of our editing team. As graduate students well trained in critical analysis, we all recognized the interpretive advantages of working on a critically overlooked text. But the tasks called for from the textual editing team were entirely new to us. Because our experience had, up to this point, been only with readyprinted books, we had never thought about the editing process itself. If at first we were undaunted by our task, it was only because we had a rather naive view of what editing entailed. We assumed that editing was simply a matter of transcribing a text and that, at the very worst, it might involve some deciphering of illegible handwriting. While we considered such matters as the standardization of spelling and punctuation and how much to preserve of the manuscript's style, these issues too, at first, seemed unproblematic. 
Our troubles began almost as soon as we laid our hands on the manuscript (or rather the photocopy of the microfilm of the manuscript). The editorial tasks we had been assigned completely changed the nature of our relationship to the text in front of us. Suddenly it was as though our responsibility to the author was much greater than it ever seemed to be in critical analysis. The handwriting of the teenage Austen represented a much more personal contact than we had ever experienced with printed texts, and somehow it humanized her. Rather than seeing her as Austen, the canonical writer of English classics, we began to see her as Jane, a young girl writing fictional letters for the amusement of her family and friends. Inexplicably, we felt a greater sense of responsibility to this girl who was at once Jane and Austen than we did when envisioning her simply as Austen. Our editorial decisions no longer seemed as straightforward, guided as we were by the desire to 'get it right,' in an effort not only to honour the ambitions of the teenage Jane, but also to validate an early production of the great author, Austen.

This new-found sense of responsibility made us suddenly highly conscious of those editors who had preceded us. How did we presume to improve upon the other extant editions of $A$ Collection of Letters contained in R. W. Chapman's Minor Works volume in The Works of Jane Austen (1954), B. C. Southam's revision of Chapman (1964), and Margaret Anne Doody's and Douglas Murray's more recent Catharine and Other Writings (1993)? For a start, our edition would present $A$ Collection of Letters as an independent work, distinct from Austen's other juvenilia, something which had not previously been done. The opportunity to publish A Collection of Letters as an independent volume, an act that we felt reflected the responsibilities we felt towards Jane, the fledgling author, was one of the advantages of editing for a small press. Most large publishing houses would not undertake the publication of a work like A Collection of Letters, simply because the cost of production would be too high, and the sales potential risky at best.

Another way in which editing for a small press enabled us to act on our sense of responsibility - this time to our twentieth-century readers - was the freedom we were given to establish our own stylistic protocol. Unhindered by 'house style,' our stylistic practices were based on our desire to convey the sense of intimacy and immediacy that we had experienced while working with the manuscript. While the most obvious way of achieving this effect is to reproduce the manuscript in facsimile, such texts are often discouraging to those who have little patience for deciphering handwriting. We compromised on this matter by using facsimiles of Austen's headings for the individual letters (see Figure 2). Other decisions we made in an effort to retain the flavour of the original included: reproducing Austen's use of the ampersand rather 




Indeed they are sw'eet Girls-. Sensible yet unafferted Accomplished yet Ensy-. Lively yet Gentle-
To Miss Cooper-1

Cousin

Conscious of the Charming Character which in every Country, \& every Clime in Christendom is Cried, Concerning you, with Caution \& Care I Com mend to your Charitable Criticism this Clever Collection of Curious Comments, which have been Carefully Culled. Collected \& Classed by your Comical Cousin

The Author.

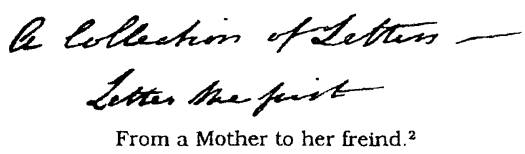

My Children ${ }^{3}$ begin now to claim all my attention in a different Manner from that in which they have been used to receive it, as they are now arrived at that age when it is necessary for them in some measure to become conversant with the World. My Augusta is $17 \&$ her Sister ${ }^{4}$ scarcely a twelvemonth younger. I flatter myself that their education has been such as will not disgrace their appearance in the World, ${ }^{5}$ \& that they will not disgrace their Educatton ${ }^{6} I$ have every reason to beleive. Indeed they are sweet Girls-. Sensible yet unaffected ${ }^{7}-$ Accomplished yet Easy-- Lively yet Gentle-. As their progress in every thing they have learnt has been always the same. I am willing to forget the difference of age ${ }^{8}$ and to introduce them together into Public. This very Evening is fixed on as their first entree into life, as we are to drink tea ${ }^{9}$ with $\mathrm{M}^{\mathrm{m}}$ Cope

Figure 2 The first opening of the Juvenilia Press edition, showing the facsimile of Austen's manuscript headings to the letters.

than changing it to 'and,' using two different dash lengths to reflect Austen's own variation, preserving the underlining rather than using italics to indicate emphasis, and maintaining Austen's idiosyncratic spelling errors.

Perhaps one of the most difficult decisions we faced as textual editors was whether to include deleted matter and to signal revisions and additions occurring in the manuscript. There are, of course, compelling reasons for including this sort of material, the foremost being that it enhances the reader's sense of direct contact with the author's process of creation. In this respect we concur with Jan Fergus, who notes in her Juvenilia Press edition of Austen's Lesley Castle, 'We have preserved as many of [Austen's deletions and insertions] as possible in our printed 
version, to allow readers the pleasure of following Austen's mind at work.... Looking at Austen's revisions makes her more familiar, more human. It gives us a chance to enter her mind - otherwise she is always way ahead or above, unpredictable and indescribable in her brilliant use of language, even as a teenager' (viii-ix). While we considered this argument in our own decision-making process, ultimately we chose not to incorporate these manuscript variants for a number of reasons: first, since the manuscript is a fairly clean copy, most of the recoverable deletions were minor, either handwriting errors or word changes. To record such minor changes, we felt, would unnecessarily interrupt the flow of reading. Moreover, Doody and Murray's 1993 edition of Austen's juvenilia provides full coverage of all the textual variants in the manuscripts. They after all had access to the original manuscript and could make plausible guesses on deletions that were illegible on our photocopy. For consistency's sake, we felt that if we could not fully recover the deletions with our manuscript, then we would not include any at all.

Having decided upon this all-or-nothing approach in the matter of deletions, we overlooked the valuable insight that these deletions can sometimes provide. While for most readers, the fact of an author having changed ' $a$ ' to 'the' is of little interest, significant changes like those in Letter the Fifth, 'From a young lady very much in love to her friend' (see Figure 3) can provide interesting insight into the creative process. While we did not include these deletions in our edition, Doody and Murray offer the following readings of the deletions, though the second one, as they point out, is 'partial and highly conjectural' (264), given Austen's heavy overscoring of the text:

1st deletion: "May I hope to receive an answer to this e'er many days have tortured me with Suspence! Any letter (post paid) will be most welcome."

2nd deletion: “T[ire]d [tho'] we shall be of one another when we are m[arrie]d [illegible] do not you long for the spring?" (264; their insertions).

In both instances, Austen's omission of the deleted material indicates a movement away from burlesque satire towards the more subtle style of her later work. In the first case (Figure 3), Austen deletes an explicit reference to Musgrove's cheapness. This stinginess and his decided interest in the fortune of his beloved is hinted at more subtly in the narrative situation and in the references to Musgrove's 'improvable estate,' without the more crude reference in the lines that Austen has crossed out. Similarly, in the second instance, the deleted matter lacks subtlety in its portrayal of the shallowness of 'the young lady.' While Austen wants us to understand that the 'young lady' is fairly shallow, we are also to understand that the young lady believes herself to be in 


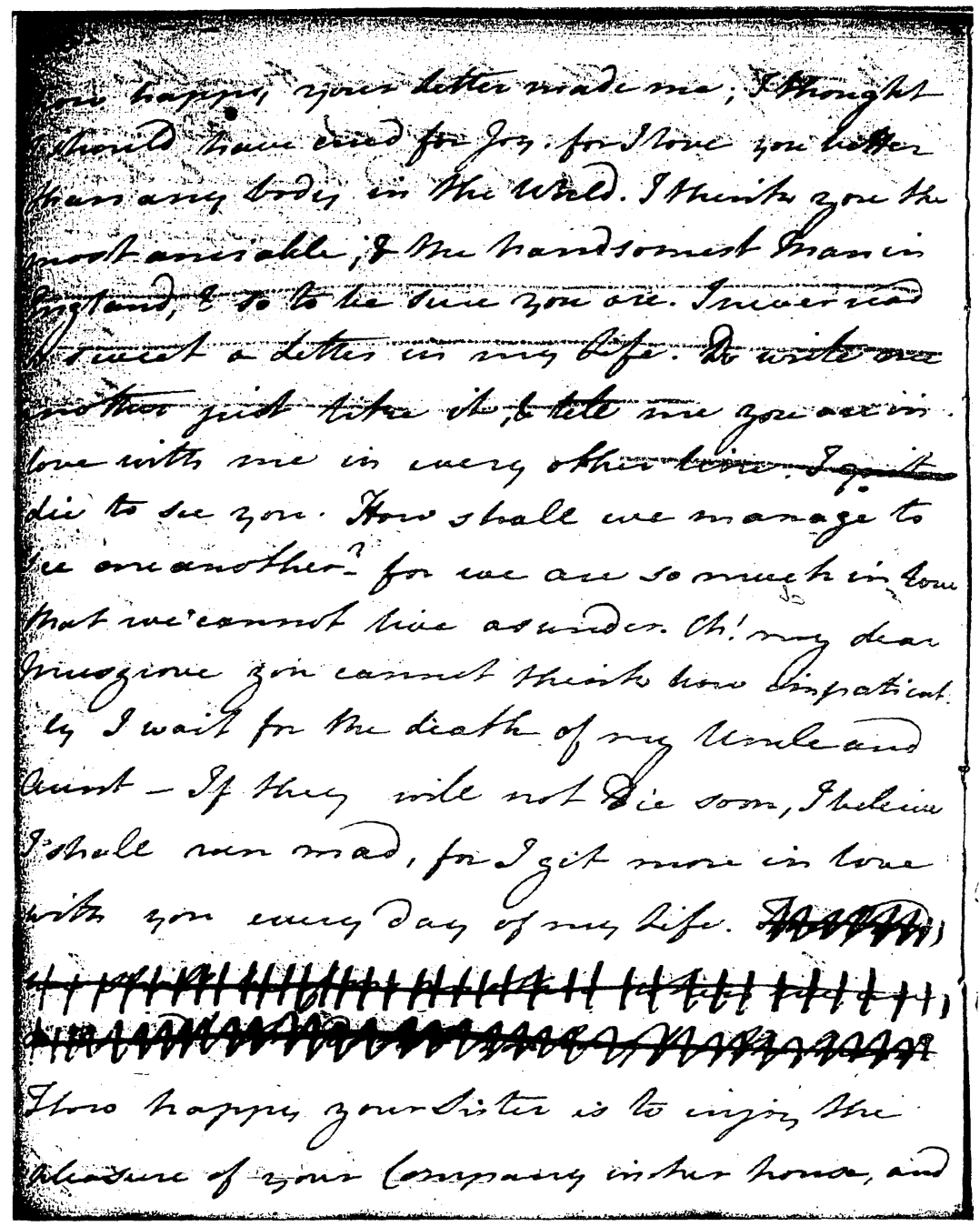

Figure 3 Page 222 of Austen's manuscript of A Collection of Letters, showing deletions. (British Library MS of Volume the Second, Add 59874)

earnest, and it is precisely this earnestness that makes her ludicrous. The deleted material suggests a worldliness in the young woman's character that somewhat undermines Austen's attempts to render this character silly. Having examined these two significant deletions for the preparation of this paper, our initial all-or-nothing approach, which at the time was guided by our desire for consistency, seems now to have been 
somewhat misguided. At the same time, however, this experience demonstrated to us that the learning process can continue even after the actual 'hands-on' part of the project is completed.

K.M.

If a desire for consistency motivated our decision regarding deletions, a respect for Austen's artistic style motivated our decision to honour, as much as possible, the different dash lengths Austen employed. ${ }^{6}$ In the manuscript, there are three basic dash lengths. The shortest dash appears most frequently; the longest dash, only a few times, and the mid-length dash, fewer still. After considering the rare occurrence of the mid-length dash as well as the possibility that at least some of the variations in dash length could have resulted not from authorial intention, but from the necessary inconsistencies of a young girl writing, by hand, with a quill pen, we decided to standardize Jane Austen's dashes to two lengths: short and long.

Our recognition of the tonal significance of the dash was intuitive. But when we delivered this paper, questions from Peter Sabor and Gary Kelly alerted us to useful scholarship on the issue. In discussing Sarah Fielding's use of dashes in David Simple (1744), Janine Barchas demonstrates how her use of the dash 'serves a vital interpretive function ... [and] conveys information through graphic rather than verbal means' (333). Henry Fielding revised his sister's punctuation, changing her dashes to more formal pointing. (He was apparently like another linguistically pedantic male, Austen's own Henry Tilney in Northanger Abbey, who castigates women's letters for their 'total inattention to stops' [Northanger Abbey 27]). In his recent edition of David Simple, Peter Sabor records 'nine different lengths of dashes, both broken and unbroken,' which he takes pains to restore (Sabor, xlii).

Another woman writer closer to Austen's time who employed different dash lengths was Eliza Fenwick. In her edition of Secresy (1795), Isobel Grundy notes that Fenwick 'apparently sought to distinguish three lengths of dash: short, to replace or reinforce a period in the manner of Sterne's Tristram Shandy; medium, to indicate material absent from the text; and very long for the inarticulacy of intense emotion' (Grundy 36).

Young Jane's practice, then, is part of a tradition particularly congenial to women writers, though shared by Tristram Shandy, who is similarly a connoisseur of graphically expressive punctuation. So much we have learned in the on-going process not only of editing but also of engaging in scholarly discourse on editing, as our paper has allowed us to do. 
Austen, too, uses the short dash to reinforce other punctuation marks. In Letter the First, for example, within a few lines, Austen uses this dash to emphasize a comma and a period: 'In a few Moments we were in $\mathrm{M}^{\text {rs }}$ Cope's parlour - , where with her daughter she sate ready to receive us. I observed with delight the impression my Children made on them - ' (CL 3-4). In Letter the Fourth, even an exclamation point receives additional emphasis from a short dash when Miss Grenville responds to the letter-writer's inquiry about from whence she travelled with a surprised 'No Ma'am - !' (CL 16).

Not only does the short dash emphasize extant punctuation, it frequently replaces other punctuation marks as well. Most commonly, such use appears within or around quotation marks. In the following exchange between Lady Greville and Maria, for example, the short dash replaces commas and periods, in addition to being used in its more conventional manner:

Why I think Miss Maria you are not quite so smart as you were last night - But I did not come to examine your dress, but to tell you that you may dine with us the day after tomorrow - Not tomorrow, remember, do not come tomorrow, for we expect Lord and Lady Clermont \& Sir Thomas Stanley's family - There will be no occasion for your being very fine for I shant send the Carriage - If it rains you may take an umbrella $-\ldots$ - And pray remember to be on time, for I shant wait - I hate my victuals over-done - But you need not come before the time - How does your Mother do - ? She is at dinner is not she? (CL 13-14)

The informality of the dash is appropriate to the unconsidered spurts of Lady Greville's speech.

Perhaps the most interesting use of the dash is as a means of characterization. In Letter the Second, the short dashes convey Sophia's breathlessness and fluster as well as the rush of thoughts and emotions which she cannot ever clearly express. When describing Miss Jane to the 'freind' to whom she writes, Sophia recalls that

There is something so sweet, so mild in her Countenance, that she seems more than Mortal. Her Conversation is as bewitching as her appearance - ; I could not help telling her how much she engaged my Admiration - . Oh! Miss Jane (said I) - and stopped from an inability of the moment of expressing myself as I could wish - "Oh! Miss Jane" - (I repeated) - I could not think of words to suit my feelings. She seemed waiting for my Speech - . I was confused distressed - My thoughts were bewildered - and I could only add - "How do you do?" (CL 5-7) 
It is in this arena of characterization and emphasis on the unspeakable that longer dash lengths come into play. In Letter the First, the letterwriting mother warns her daughters 'against suffering yourselves to be meanly swayed by the Follies \& Vices of others, for beleive me my beloved Children that if you do - - I shall be very sorry for it' (CL 3). The long dash here not only represents the pause in the mother's speech, it also articulates the unspeakable possibility of the girls' being led astray. Likewise, at the close of the conversation Maria Williams has with her mother in Letter the Third, the long dash represents a pause in the dialogue as well as an (in)audible expression of Maria's protest: "Go Maria - " replied She - - Accordingly I went \& was obliged to stand there at her Ladyships pleasure' (CL 13). If we had not differentiated the few long dashes from the plethora of short ones, we might have obliterated the ways in which young Jane Austen's use of the dash invested in that symbol a significance and a currency which professional women writers like Fielding, Inchbald, and Fenwick were also discovering and employing.

Questions about leaving out deletions and maintaining (although standardizing) different dash lengths we answered democratically. So, too, did we decide upon whether a ' $c$ ' or an ' $a$ ' was a capital or lower case letter and whether a mark on a page was a comma, a period, or a blot. The ultimate arbitrariness of some of our decision-making made us suspect that even more experienced manuscript editors at times work through a similarly subjective process. This realization was a comfort to us tyros, who felt daunted by the previous editions of $A$ Collection of Letters in the volumes by Doody and Murray and by Chapman.

Our confidence in our ability as editors increased greatly and naively when we discovered an error in the edition by Chapman as revised by Southam which was repeated in that by Doody and Murray. In 'Letter the First,' where these editions read 'When we arrived at Warleigh, poor Augusta could hardly breathe' (Southam 151, Doody and Murray 147), the manuscript itself reads 'could scarcely breathe' (Austen MS 92, our emphasis; see Figure 4). While allowing us to believe ourselves capable of engaging with contemporary Austen scholarship, the fact that we were able to correct the two most recent (and authoritative) editors, even in this small way, simultaneously reminded us of the subjectivity of textual editing (including the deciphering of handwriting) and of the fallibility of even professional editors.

Our own fallibility came to the fore in circumstances surrounding another of our corrections. At the very end of the manuscript, in Southam's Chapman, the emphasis of the 'I $\mathrm{am}^{\prime}$ ' on page 169 is reversed: rather than saying 'I am very Charitable every now and then,' in Southam's Chapman, Henrietta Halton says 'I am' so. We gleefully 




Figure 4 Page 192 of the manuscript, showing "could scarcely breathe" where some other editions read "could hardly breathe." (British Library MS of Volume the Second, Add 59874)

pounced on the error, and congratulated ourselves on the correction in a note. Only subsequently did we discover that Doody and Murray had got there before us. Thus, not only was our second correction less exciting because not as far-reaching, it was humbling as well.

Working on a piece of fiction by a canonical author on whom we were not experts was an intimidating and fascinating experience. During moments of uncertainty and self-doubt, we questioned our endeavour. In the face of the previous professional editors and their authoritative editions, who were we? what did we have to offer? In the height of our enthusiasm, the questions changed: what did we not have to offer? From the deciphering of handwriting, the deciding upon our own stylistic practices, and the comparison of our copy text with previous editions to the arguments we had over the incorporation of deletions, the rendering of two dash lengths, and the painstakingly-produced Note on the Text, our work as textual editors provided us with an invaluable experience. Perhaps most importantly, the practical experience of working on this Juvenilia Press volume catalyzed a critical re-evaluation of our primary tool as literary scholars - the printed text - in illuminating and disillusioning ways. Now, inevitably, we question the authenticity of all books, including our own, for we can no longer view printed texts as unadulterated reproductions of authors' original drafts. Regarding our own volume, in particular, we realize that although there are things in which we still delight, there are also things we would like to change. Yet at the very least, with our Juvenilia Press edition of Jane Austen's A 
Collection of Letters, we have found a way to engage in a new kind of scholarly dialogue, and we have opened up additional space for future editors of Jane Austen's juvenilia - not a giant feat, perhaps, but certainly a worthwhile one.

T.K.

\author{
TOBI KOZAKEWICH \\ KIRSTEN MACLEOD \\ JULIET MCMASTER \\ University of Alberta
}

\title{
Notes
}

1 We are grateful to Robert and Kathryn Merrett for their generosity in making the volume of a Collection of Letters a part of the registration package.

2 For an account of the early history of the Juvenilia Press, see Juliet McMaster, 'Apprentice Scholar, Apprentice Writer.'

3 See, for example, 'Juvenile Writings: Theoretical and Practical Approaches,' by Kathy Chung, Juliet McMaster and Leslie Robertson.

4 See J. David Grey's Jane Austen's Beginnings for a collection of critical essays on the juvenilia. A Collection of Letters, however, receives only passing reference in this volume.

5 For our own edition of $A$ Collection of Letters we use the abbreviation $C L$.

6 In the version of this essay which we read at the CSECS conference, there was scarcely a passing reference to the different dash lengths in the manuscript; however, in the question period following our panel, the comments of Gary Kelly and Peter Sabor showed us how useful further elaboration on this subject could be.

\section{Works Cited}

Alexander, Christine, and others, eds. Branwell's Blackwood's Magazine. By Branwell and Charlotte Bronte. Edmonton: Juvenilia P, 1995.

Austen, Jane. Northanger Abbey and Persuasion. Vol 5. The Novels of Jane Austen. 5 vols. Ed. R. W. Chapman. 3rd. ed. London: Oxford UP, 1954.

. Volume the Second. Ms. Add 59874. British Library, London.

Barchas, Janine. 'Sarah Fielding's Dashing Style and Eighteenth-Century Print Culture.' ELH 63 (1996): 633-56.

Chapman, R. W., ed. Minor Works. Vol 6. The Works of Jane Austen. 6 vols. Oxford: Oxford UP, 1954. 
Chung, Kathy, Juliet McMaster, and Leslie Robertson. 'Juvenile Writings: Theoretical and Practical Approaches.' English Studies in Canada 24.3 (1998): 289-320.

Doody, Margaret Anne, and Douglas Murray. Catharine and Other Writings. By Jane Austen. Oxford: Oxford UP, 1993.

Fergus, Jan, and others, eds. The History of England. By Jane Austen. Edmonton: Juvenilia $\mathrm{P}, 1995$. . Lesley Castle. By Jane Austen. Edmonton: Juvenilia P, 1998.

Grey, J. David, ed. Jane Austen's Beginnings: The Juvenilia and Lady Susan. Ann Arbor: UMI Research P, 1989.

Grundy, Isobel. Note on the text. Secresy. 1795. By Eliza Fenwick. Peterborough, Ont.: Broadview, 1994. 36. and Susan Hillabold, eds. Indamora to Lindamira. By Lady Mary Pierrepont (Wortley Montagu). Edmonton: Juvenilia P, 1994.

Hartnick, Karen L., Rachel Brownstein, and others, eds. Henry and Eliza. By Jane Austen. Edmonton: Juvenilia P, 1996.

McMaster, Juliet. 'Apprentice Scholar, Apprentice Writer.' English Studies in Canada 22.1 (1996): 1-15. and others, eds. A Collection of Letters. By Jane Austen. Edmonton: Juvenilia P, 1998.

Sabor, Peter. Note on the text. The Adventures of David Simple and Volume the Last. 1744 and 1753. By Sarah Fielding. Lexington, Kentucky: UP of Kentucky, 1998.

Southam, B.C., rev. Minor Works. Vol 6. The Works of Jane Austen. Ed. R. W. Chapman. Oxford: Oxford UP, 1963. 